\title{
Factors Associated with the Stunting in Toddlers in the Work Area of Tikson Raya Public Health Center
}

\author{
Rasyika Nurul Fadjriah*, Rusdianto Rusdianto, Herman Herman, Vidyanto Vidyanto
}

Department of Public Health, Tadulako University, Palu, Indonesia

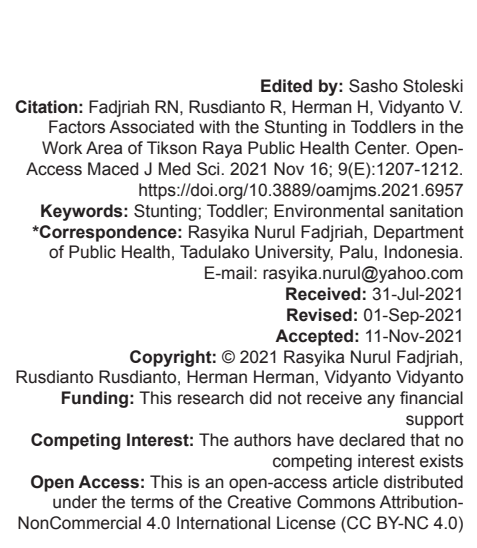

Introduction

Sustainable Development Goals (SDGs) have been agreed upon by various countries as a goal must be achieved to answer the lagging development of countries worldwide. The second goal of the SDGs is to end hunger, achieve food security, improve nutrition, and promote sustainable agriculture. Those all are based on one indicator; specifically, by 2030 , all countries in the world can end all forms of nutritional problems, including achieving the international target of 2025 of reducing stunting and wasting in Indonesia under 5 by $40 \%$ [1].

According to the UNICEF (2018) [2], stunting is still a global public health problem. This is reinforced by several survey results regarding stunting conducted in various parts of the world, the prevalence of stunting worldwide in 2018 was $21.9 \%$, Africa of $30 \%$, Central Africa of $32.1 \%$, South Africa of $29.3 \%$, Asia of $22.7 \%$, Southeast Asia of $25 \%$, Central Asia of $10.9 \%$, and South Asia of $32.7 \%$.

Kemenkes (201) [3] stated that of 34 provinces in Indonesia, the highest stunting in children aged 0-59 months was in East Nusa Tenggara (42.7\%) and followed by West Sulawesi Province (41.6\%) and Aceh
Province $(37.10 \%)$. Meanwhile, the lowest prevalence was DKI Jakarta (17.60\%), DI Yogyakarta $(21.40 \%)$, and Bali $(21.90 \%)$. Central Sulawesi was in $13^{\text {th }}$ place with a prevalence of stunting under- 5 children of $32.3 \%$. Of the 13 districts/cities in Central Sulawesi, the highest prevalence of stunting under 5 in 2018 was in Banggai Laut District (36.7\%), followed by Bangkep District (35.8\%), North Morowali District (34.3\%), and Donggala District (32,8\%). Meanwhile, the district with the lowest prevalence of stunting under 5 was Touna District is the name of a district in Central Sulawesi Province, Indonesia (15.7\%) [4].

The prevalence of stunting cases for toddlers in Banggai Laut District in 2018 was $36.7 \%$. The number of stunting cases was 617 toddlers out of 1735 toddlers measured in height. In 2019, there was a decrease of $23 \%$, with the number of stunting cases being 946 toddlers from 4040 toddlers measured by height. Stunting is still a public health problem that must be suppressed because its prevalence is still above $20 \%$. Of the 10 health centers in Banggai Laut District, Tikson Raya Health Center has the highest prevalence of stunting in Banggai Laut District. About $30 \%$ or 57 children out of 191 children under 5 were measured in height [5].

Based on the problems above, the authors are interested in studying the factors related to the incidence 
of stunting in toddlers in the working area of the Tikson Raya Public Health Center, Banggai Laut District.

\section{Methods}

It was quantitative with a case-control research design. This research was conducted in the Working Area of the Tikson Raya Public Health Center, Bokan Islands Sub-district, Banggai Laut District, during January-February of 2020 . The population in this study were all toddlers living in the working area of the Tikson Raya Health Center, Bokan Islands Subdistrict, Banggai Laut District, about 191 toddlers. About 90 people were chosen as samples, determined by the Lemeshow formula. The sampling technique is proportional stratified random sampling, a sampling technique when the population has elements that are not homogeneous and proportionally stratified.

The primary data were collected through questionnaires and interviews. Data analysis was performed using Chi-square statistical test at 95\% confidence level $(\alpha=0.05)$ and odds ratio (OR)

\section{Results}

Table 1 shows that out of 90 toddlers in the working area of the Tikson Raya Public Health Center, most of them did not obtain appropriate exclusive breastfeeding, about 50 people $(55.6 \%)$. In comparison, toddlers obtained exclusive breastfeeding were 40 people (44.4\%). Most of the toddlers obtained complementary breastfeeding before the age of $<6$ months (50 people/55.6\%). Most of the toddlers who had a history of infectious diseases were 38 people (42.2\%). Most of the children under 5 had poor basic health practices (23 people/25.6\%). Anyhow, toddlers who had good basic health practices were 67 people (74.4\%). Toddlers with poor environmental sanitation hygiene were 29 people (32.2\%). Respondents with low nutritional knowledge were 29 people (30.0\%).

Table 2 shows that out of 30 stunted toddlers, most of them did not obtain exclusive breastfeeding, about 23 toddlers (76.7\%). Meanwhile, 60 toddlers who were not stunted, most of the toddlers obtained exclusive breastfeeding, about 33 toddlers (55.0\%).

Table 2 shows that $p=0.009$, there was an association between exclusive breastfeeding and the incidence of stunting, while the results of the OR test were 4.016 (1.496-10.777). Hence, toddlers who were not obtaining exclusive breastfeeding had a 4.016 times greater risk of stunting than those who obtained exclusive breastfeeding. There was an association between the
Table 1: Characteristics of respondents

\begin{tabular}{|c|c|c|}
\hline Characteristics & $\mathrm{N}$ & $\%$ \\
\hline \multicolumn{3}{|l|}{ Age toddlers (months) } \\
\hline $8-14$ & 10 & 11.1 \\
\hline $15-21$ & 12 & 13.3 \\
\hline $22-28$ & 16 & 17.8 \\
\hline $29-35$ & 14 & 15.6 \\
\hline $36-42$ & 16 & 17.8 \\
\hline $43-49$ & 13 & 14.4 \\
\hline $50-56$ & 7 & 7.8 \\
\hline $57-63$ & 2 & 2.2 \\
\hline \multicolumn{3}{|l|}{ Sex toddlers } \\
\hline Male & 39 & 43.3 \\
\hline Female & 51 & 56.7 \\
\hline \multicolumn{3}{|l|}{ Mother's education } \\
\hline Elementary education & 58 & 64.4 \\
\hline Junior high school & 17 & 18.9 \\
\hline Senior high school & 13 & 14.4 \\
\hline Bachelor & 2 & 2.3 \\
\hline \multicolumn{3}{|l|}{ Father's occupation } \\
\hline Farmer & 5 & 5.6 \\
\hline Fisherman & 74 & 82.2 \\
\hline Self-employed & 4 & 4.4 \\
\hline Honorary & 6 & 6.7 \\
\hline Civil servant & 1 & 1.1 \\
\hline \multicolumn{3}{|l|}{ Mother's job } \\
\hline Housewife & 85 & 94.4 \\
\hline Self-employed & 2 & 2.2 \\
\hline Honorary & 3 & 3.3 \\
\hline \multicolumn{3}{|l|}{ Family income (Rupiah) } \\
\hline$\leq 500,000$ & 70 & 77.8 \\
\hline$>500,000$ & 20 & 22.2 \\
\hline \multicolumn{3}{|l|}{ History of exclusive breastfeeding } \\
\hline No exclusive breastfeeding & 50 & 55.6 \\
\hline Yes exclusive breastfeeding & 40 & 44.4 \\
\hline \multicolumn{3}{|l|}{ Breastfeeding time (months) } \\
\hline$<6$ & 50 & 55.6 \\
\hline$\geq 6$ & 40 & 44.4 \\
\hline \multicolumn{3}{|l|}{ History of infectious diseases } \\
\hline Yes & 38 & 42.2 \\
\hline No & 52 & 57.8 \\
\hline \multicolumn{3}{|l|}{ Basic health practice } \\
\hline Not good & 23 & 25.6 \\
\hline Good & 67 & 74.4 \\
\hline \multicolumn{3}{|l|}{ Environmental sanitation hygiene } \\
\hline Not good & 29 & 32.2 \\
\hline Good & 61 & 67.8 \\
\hline \multicolumn{3}{|l|}{ Mother's nutrition knowledge } \\
\hline Low & 27 & 30.0 \\
\hline Good & 63 & 70.0 \\
\hline
\end{tabular}

time of giving complementary breastfeeding to the incidence of stunting in toddlers with $p=0.009(p<0.05)$ and the OR test was $4.016(1.496-10.777)$ with a $95 \%$ confidence interval $(\mathrm{Cl})$. Hence, toddlers who obtained complementary breastfeeding $<6$ months were at risk of becoming stunted, 4.016 times greater than toddlers who obtained complementary breastfeeding at 6 months.

The OR test was 5.902. (2256-15,442) with a $95 \% \mathrm{Cl}$. Since the value of OR> 1 and the lower (2.256) and upper (15.442) values did not include the number 1 ,

Table 2: Variables that correlate with stunting

\begin{tabular}{|c|c|c|c|c|c|c|c|c|}
\hline \multirow[t]{3}{*}{ Variable } & \multicolumn{4}{|c|}{ Stunting } & \multirow{2}{*}{\multicolumn{2}{|c|}{ Total }} & \multirow[t]{3}{*}{$p$-value } & \multirow[t]{3}{*}{ OR } \\
\hline & \multicolumn{2}{|c|}{ Yes } & \multicolumn{2}{|l|}{ No } & & & & \\
\hline & $\mathrm{n}$ & $\%$ & $\mathrm{n}$ & $\%$ & $\mathrm{n}$ & $\%$ & & \\
\hline \multicolumn{9}{|c|}{ History of exclusive breastfeeding } \\
\hline No & 23 & 76.7 & 27 & 45.0 & 50 & 100 & 0.009 & $4.016(1.496-10.777)$ \\
\hline Yes & 7 & 23.3 & 33 & 55.0 & 40 & & & \\
\hline \multicolumn{9}{|c|}{ Breastfeeding time (months) } \\
\hline$<6$ & 23 & 76.7 & 27 & 45.0 & 50 & 100 & 0.009 & $4.016(1.496-10.777)$ \\
\hline$\geq 6$ & 7 & 23.3 & 33 & 55.0 & 40 & & & \\
\hline \multicolumn{9}{|c|}{ History of infectious diseases } \\
\hline Yes & 21 & 70.0 & 17 & 28.3 & 38 & 100 & 0.000 & $5.902(2.256-15.442)$ \\
\hline No & 9 & 30.0 & 43 & 71.7 & 52 & & & \\
\hline \multicolumn{9}{|c|}{ Basic health practice } \\
\hline Not good & 16 & 53.3 & 7 & 11.7 & 23 & 100 & 0.000 & $8.653(2.981-25.119)$ \\
\hline Good & 14 & 46.7 & 53 & 88.3 & 67 & & & \\
\hline \multicolumn{9}{|c|}{ Environmental sanitation hygiene } \\
\hline Not good & 24 & 80.0 & 5 & 8.3 & 29 & 100 & 0.000 & $44.000(12.233-158.255)$ \\
\hline Good & 6 & 20.0 & 55 & 91.7 & 61 & & & \\
\hline \multicolumn{9}{|c|}{ Mother's nutrition knowledge } \\
\hline Low & 21 & 70.0 & 6 & 10.0 & 27 & 100 & 0.000 & $21.000(6.653-66.823)$ \\
\hline Good & 9 & 30.0 & 54 & 90.0 & 63 & & & \\
\hline
\end{tabular}


so toddlers with a history of infectious diseases may 5.902 times greater risk of becoming stunted compared to children with no history of infectious disease (Table 2). The results of the Chi-square test analysis showed that $p=0.000$, there was an association between basic health practices and the incidence of stunting in children under 5 in the working area of the Tikson Raya Public Health Center. The OR test was $8.653(2.981-25.119)$ with a $95 \% \mathrm{Cl}$. The OR value $>1$ and the lower $(2981)$ and upper $(25,119)$ values did not include 1 , so toddlers who practice poor basic health had a risk of becoming stunted 8.653 times higher compared to toddlers who practiced good basic health. There was an association between environmental sanitation hygiene and the incidence of stunting with $p=0.000$. There was an association between maternal nutritional knowledge and the incidence of stunting with the OR test which were $21,000(6653-66,823)$ with a $\mathrm{Cl}$ $95 \%$. Toddlers with low maternal nutrition knowledge risk becoming stunted 21,000 times greater than toddlers with sufficient maternal nutrition knowledge.

\section{The most significant associated factors to stunting}

Based on Table 3, the modeling that was tested simultaneously showed that two independent variables had a significant relationship to the dependent variable; the environmental sanitation hygiene variable with $p=0.000$ (< 0.05 ) and the mother's nutritional knowledge variable with $p=0.017(<0.05)$. There are four other variables such as infectious diseases ( $p$-value $=0.178)$, basic health practices $(p$-value $=0.321)$, and breastfeeding and complementary feeding ( $p$-value $=0.808)$ not significantly related to the incidence of stunting ( $p$-value $>0.05$ ). Of the six variables tested multivariate, the environmental sanitation hygiene variable was most associated with the incidence of stunting with $p=0.000$ and a $B$ value of 17.874 . This means that toddlers who had less environmental sanitation might 17.874 times greater risk of becoming stunted than toddlers with good environmental sanitation hygiene.

Table 3: Multivariate Analysis of Factors Associated with Stunting

\begin{tabular}{|c|c|c|c|c|}
\hline \multirow{3}{*}{ Variables } & \multicolumn{4}{|c|}{ Modeling } \\
\hline & \multirow[t]{2}{*}{ sig } & \multirow[t]{2}{*}{$\operatorname{Exp}(B)$} & \multicolumn{2}{|c|}{ 95\% C.I. EXP(B) } \\
\hline & & & Lower & Upper \\
\hline History of Exclusive Breastfeeding & 0.808 & 0.826 & 0.177 & 3.851 \\
\hline Breastfeeding Time & 0.808 & 0.826 & 0.177 & 3.851 \\
\hline History of Infectious Diseases & 0.178 & 2.890 & 0.617 & 13.535 \\
\hline Basic Health Practice & 0.321 & 2.273 & 0.449 & 11.507 \\
\hline Environmental Sanitation Hygiene & 0.000 & 17.874 & 4.014 & 79.603 \\
\hline Mother's Nutrition Knowledge & 0.017 & 6.265 & 1.395 & 28.141 \\
\hline
\end{tabular}

\section{Discussion}

\section{Association of exclusive breastfeeding with stunting}

One of the failure factors for newborns is prelacteal feeding [6]. Pre-lacteal food is food or drinks other than breast milk given to a baby 1-3 days after birth because breast milk has not come out or milk has come out little by little. For traditional reasons, prelacteal feeding can be given by birth attendants or the baby's parents and family [7].

Fulfilling the needs of infants $0-6$ months can be met with breastfeeding alone. Exclusive breastfeeding is also important because, at this age, food other than breast milk has not been digested by the enzymes in the intestines. Besides that, the waste of food burning cannot be done correctly because the kidneys are not perfect [8]. It is known that previous research in China by Jiang et al. (2014) [9] also showed that inappropriate exclusive breastfeeding leads to stunting in children under 3 y.o.

\section{Association between the time of giving complementary breastfeeding with stunting}

Giving complementary breastfeeding too early by mothers of toddlers is due to the cessation of exclusive breastfeeding and the perception that arises from mothers that breast milk is not enough. Breast milk does not come out smoothly so that children are fussy. Finally, the mother gave additional food to the child. Early complementary breastfeeding will impact the incidence of high infections such as diarrhea, respiratory tract infections, and allergies, to growth disorders because the baby's digestive system is still not functioning perfectly [10]. Impaired growth at the beginning of a baby's life, among others, is caused by malnutrition since infancy and giving complementary breastfeeding too early or too late. Children under 5 who are given exclusive breastfeeding and complementary feeding according to their needs can reduce the risk of stunting [11].

Based on Tessema et al. (2013) [12], the timing of giving complementary breastfeeding was associated with stunting. Children who were given complementary feeding before 6 months had a 3.2 times greater risk of experiencing stunting. It is estimated that 165 children experience stunting due to complex effects, one of which is the provision of complementary feeding in the form of too early delivery or low nutrition content [13]. In addition, the importance of giving complementary breastfeeding shows that this factor can be a predictor of stunting in children. The complementary feeding stage shows potential in reducing stunting in children in the northern province of Rwanda [14].

\section{Association of history of infectious diseases with stunting incidence}

Infectious diseases can affect the nutritional status of children under 5 by reducing nutritional intake, reducing food absorption caused by intestinal damage, and increasing nutrient requirements due to increased metabolism. Even if only a mild infection occurs, it will cause nitrogen loss. Acute infection results in a lack of 
appetite and will cause disturbances in the absorption of nutrients in the body [15].

Infectious diseases such as respiratory tract infections and diarrhea can continually worsen nutritional conditions. This is because when a toddler is exposed to an infectious disease, the toddler lacks appetite. Even though the toddler eats, the food is not absorbed into the body. Through disturbances in food intake and loss of essential substances in the body, the impact of infectious diseases on growth, such as decreased body weight of infected people to intake of nutrients and energy, is less than needed. In the long term, it can cause chronic nutritional problems such as stunting. Infectious diseases harm the nutritional status of children in terms of reducing appetite and absorption of nutrients in the intestines. There is an increase in catabolism so that the available nutrient reserves are not sufficient for body tissue formation and growth [16].

This study is in line with Solin et al. (2019) [17] that toddlers who experience diarrhea with stunting are $93.3 \%$ with the results obtained $p$-value $(0.000)<(\alpha=0.05)$ stating that there is a strong relationship between disease diarrheal infection on the incidence of stunting in children under 5 . This is supported by research Rizaldi (2019) [18] that the results of the analysis of the OR of 5.114 (2.216-11.804) with a $\mathrm{Cl}$ of $95 \%$, because the OR value $>1$ and the lower (2.216) and upper (11.804) values, higher of 1 , then a history of infectious disease is a risk factor for stunting. Toddlers with a history of infectious diseases have a 5.114 times greater risk of stunting than toddlers who do not have a history of infectious diseases.

Diarrhea is one of the most common infectious diseases experienced by children who live in an environment with poor sanitation. Previous research in Nepal showed that this infectious disease was positively correlated with the incidence of stunting with $\mathrm{OR}=7.46,95 \% \mathrm{Cl}$ 2.98-18.65). Hence, in other words, environmental health must be maintained to reduce stunting in children [19].

\section{Association of basic health practices to stunting incidence}

The purpose of immunization is to reduce morbidity, disability, and death from diseases prevented by immunization. Completeness of immunization has a significant effect on stunting. Immunization has an immune effect on humans, and it is needed especially at an early age which is an age susceptible to disease. The impact of the frequent and easy disease is a problem of nutritional status [20].

This study is in line with Imelda et al. (2018) [21] that complete basic immunization is a risk factor for stunting, that the case group of children who did not receive complete basic immunization (76.7\%) was more than children who received complete basic immunization $(23,3 \%)$. On the other hand, in the control group, more children received complete basic immunization $(70 \%)$ than those who did not receive complete basic immunization (30\%), with an OR value of 7.667, meaning that children who were not given immunization had a risk of 7.667 times the chance of becoming stunted. According to Swathma et al. [20], based on the analysis of the risk of basic immunization history on the incidence of stunting, an OR of 6.044 was obtained. Respondents who have toddlers with a history of incomplete basic immunization have a 6.044 times greater risk of experiencing stunting compared to respondents who have toddlers with a history of complete basic immunization.

\section{Association of environmental sanitation hygiene to stunting incidents}

From the results of interviews with respondents, several factors make some respondents still have poor environmental sanitation hygiene, including starting there are some mothers if after defecation do not wash their hands with soap, children's habits when playing outside the house do not wear footwear, still lack of ownership toilet.

An environment that does not meet health requirements allows the occurrence of various types of diseases, including diarrhea, intestinal worms, respiratory tract infections, digestive tract infections, and the absorption of food nutrients will be disrupted, which causes malnutrition and will be susceptible to disease and children's growth will be disrupted [22].

Nutritional problems can be caused by unhygienic behavior that can cause infectious diseases. Children's hygiene practices usually depend on the behavior that the mother and the environment exemplify. Good hygiene habits need to be cultivated from childhood which is expected to continue into adulthood. Body hygiene, food, and the environment play an important role in maintaining children's health and preventing infectious diseases [23]. The habit of washing hands before eating and after defecating has become the focus of the WHO to reduce infectious diseases such as diarrhea.

Improvements in sanitation and clean living habits are closely associated with stunting in several previous studies. In India, rural areas with suitable environmental sanitation show lower stunting rates than areas with good sanitation [24].

\section{Association of maternal nutrition knowledge to stunting incidence}

The high level of maternal education also affects the ability to receive information about nutrition and health for growing children. On the other hand, if a mother has a low level of education, it can be said that 
there is little information that the mother can receive regarding nutrition and health. This can impact how the mother takes care of the family, especially in choosing good food and food that can fulfill the child's nutrition. Low maternal education also makes it possible for mothers not to know information or knowledge about health to increase the possibility of their child getting an infection or a disease. If this continues, it will affect children's nutritional status, resulting in a child being stunted [16].

The mother's high level of nutrition knowledge can affect the toddler's diet and will eventually affect the toddler's nutritional status. If the mother's knowledge is good, then the mother can choose and provide food for toddlers both in terms of quality and quantity that can meet the nutritional adequacy rate needed by toddlers to affect the nutritional status of the toddlers [25]. The mother's level of knowledge is the key in household management, and this will affect the mother's attitude in choosing food ingredients that the family will consume. Mothers with good nutritional knowledge will understand and understand the importance of good nutritional status for health and well-being [26].

\section{Factors most related to stunting}

Stunting can occur due to direct or indirect factors. The direct factors for stunting are maternal nutrition during pregnancy, infectious diseases, and under-5 nutrition, while indirect factors can occur from various aspects. One of the indirect factors causing stunting is water, sanitation, and hygiene (WASH), consisting of drinking water sources, physical quality of drinking water, latrine ownership, and hygiene by hand washing habits. WASH affects the nutritional status of stunting in children under 5 , namely, through infectious diseases experienced [27].

Poor sanitation is also a factor that can cause stunting related to the possibility of the emergence of infectious diseases. A healthy latrine is a good means of disposing of feces to stop the chain of spreading disease. Toilets that meet health requirements do not cause a direct spread of human waste and can prevent disease carrying vectors in latrine users and the surrounding environment [28].

The existence of latrines is the most influential factor in the nutritional status of body height/age. The nutritional status can be influenced by the environment, such as supply factors and waste disposal (latrines). The role of latrines concerning the nutritional status of children under 5 is related to the pollution used for daily household consumption. The use of polluted water can cause disease that affects nutritional status [29].

The source of drinking water cannot be separated from the physical quality of drinking water. Based on the Regulation of the Minister of Health of the Republic of Indonesia No.492/MENKES/PER/IV/2010 concerning the requirements for drinking water quality, drinking water is safe for health if it meets the physical, microbiological, chemical, and radioactive requirements. The parameters used to see the good physical quality of water meet the requirements of not cloudy, tasteless, odorless, and colorless [30]. According to Gibney [31], the availability of safe water, preparation of clean food, and proper disposal of waste are essential elements in preventing short bodies or chronic malnutrition.

The results of this study are in line with Hapsari et al. [32], the personal hygiene variable has $p<0.005$, and the largest OR value is 12.027 . This means that toddlers with poor environmental sanitation risk becoming stunted 12,027 times greater than good environmental sanitation.

\section{Conclusion}

Exclusive breastfeeding, complementary breastfeeding, infectious diseases, basic health practices, environmental sanitation, and knowledge of maternal nutrition are associated with the incidence of stunting in toddlers in the working area of Tikson Raya Public Health Center, Banggai Laut District. It is recommended that Public Health be more active in providing counseling about exclusive breastfeeding. They may always provide education to mothers about the types of infectious diseases. Then, families of toddlers know and prevent them from getting infected. Furthermore, the public health centers should collaborate with the government of the sub-district to the district government to fix environmental sanitation starting from the construction of sewerage and drinking water management according to standards, and the public health centers should be more active in providing counseling about nutrition.

\section{References}

1. BPS. Potret Awal Tujuan Pembangunan Berkelanjutan (Sustainable Development Goals) di Indonesia. Jakarta: Badan Pusat Statistik; 2016.

2. UNICEF. Joint Malnutrition Estimates Regional and Global Estimates. United Nations Children's Fund; 2018.

3. KEMENKES RI. Profil Kesehatan Indonesia 2018. Jakarta: Kementerian Kesehatan RI; 2019.

4. Sulteng D. Profil Kesehatan Provinsi Sulawesi Tengah Tahun 2017. Palu: Dinas Kesehatan Sulawesi Tengah; 2018.

5. Balut D. Profil Kesehatan Banggai Laut. Banggai: Dinas Kesehatan Banggai Laut; 2019.

6. KEMENKES RI. Modul Pelatihan Konseling Menyusui. Jakarta: Kementerian Kesehatan RI; 2015

7. KEMENKES RI. Situasi dan Analisis ASI Eksklusif. Jakarta 
Kementerian Kesehatan RI; 2014.

8. Larasati NN, Wahyuningsih, Margono. Faktor-faktor Yang Berhubungan Dengan Kejadian Stunting Pada Balita Usia 25-59 Bulan di Posyandu Wilaya Puskesmas Wonosari II Tahun 2017. Yogyakarta: Poltekkes Kemenkes Yogyakarta; 2018.

9. Jiang $\mathrm{Y}$, Su X, Wang $\mathrm{C}$, Zhang L, Zhang X, Wang L, et al. Prevalence and risk factors for stunting and severe stunting among children under three years old in mid-western rural areas of China. Child Care Health Dev. 2014;41(1):45-51. http://doi. org/10.1111/cch.12148 PMid:24797895

10. Fitri L, Ernita E. Hubungan pemberian asi eksklusif dan $\mathrm{mp}$ as dini dengan kejadian stunting pada balita. Al-Insyirah Midwifery. 2019;8(1):19-24.

11. Khasanah DP, Hadi $\mathrm{H}$, Paramashanti BA. Waktu pemberian makanan pendamping ASI (MP-ASI) berhubungan dengan kejadian stunting anak usia 6-23 bulan di Kecamatan Sedayu. J Gizi Dietetik Indones. 2016;4(2):105-11.

12. Tessema M, Belachew T, Ersino G. Feeding patterns and stunting during early childhood in rural communities of Sidama, South Ethiopia. Pan Afr Med J. 2013;14:75. http://doi. org/10.11604/pamj.2013.14.75.1630 PMid:23646211

13. Stewart CP, lannotti L, Dewey KG, Michaelsen KF, Onyango AW. Contextualising complementary feeding in a broader framework for stunting prevention. Matern Child Nutr. 2013;9(S2):27-45. http://doi.org/10.1111/mcn.12088 PMid:24074316

14. Uwiringiyimana V, Ocké MC, Amer S, Veldkamp A. Predictors of stunting with particular focus on complementary feeding practices: A cross-sectional study in the northern province of Rwanda. Nutrition. 2019;60:11-8. http://doi.org/10.1016/j. nut.2018.07.016

PMid:30508763

15. Adriani M. Gizi Dan Kesehatan Balita. Jakarta: Kencana; 2014.

16. Lestari W, Margawati A, Rahfiludin Z. Faktor risiko stunting pada anak umur 6-24 bulan di kecamatan Penanggalan kota Subulussalam provinsi Aceh. J Gizi Indones. 2014;3(1):37-45.

17. Solin AR, Hasanah $O$, Nurchayati $S$. Hubungan kejadian penyakit infeksi terhadap kejadian stunting pada balita 1-4 Tahun. J Online Mahasiswa Bidang IImu Keperawatan. 2019;6(1):65-71.

18. Rizaldi M. Determinan Stunting Pada Balita Usia 24-59 Bulan di Wilayah Kerja Puskesmas Tompe. Palu: Universitas Tadulako; 2019.

19. Paudel R, Pradhan B, Wagle RR, Pahari DP, Onta SR. Risk factors for stunting among children: A community based case control study in Nepal. Kathmandu Univ Med J. 2012;10(3):18-24. http://doi.org/10.3126/kumj.v10i3.8012

PMid:23434956

20. Swathma D, Lestari H, Ardiansyah RT. Riwayat imunisas dasar terhadap kejadian stunting pada balita usia 12-36 bulan di wilayah kerja puskesmas kandai kota kendari tahun 2016 J IImiah Mahasiswa Kesehatan Masyarakat. 2016;1(3):1088.

21. Imelda I, Rahman N, Nur R. Faktor risiko kejadian stunting pada anak umur 2-5 tahun di puskesmas biromaru. Ghidza. 2018;2(1):39-43.

22. Husin CR. Hubungan Pola Asuh Anak Dengan Status Gizi Balita Umur 24-59 Bulan Di Wilayah Terkena Tsunami Kabupaten Pidie Provinsi Nanggroe Aceh Darussalam. Medan: Universitas Sumatera Utara; 2008.

23. Mbuya MN, Humphrey JH. Preventing environmental enteric dysfunction through improved water, sanitation and hygiene: An opportunity for stunting reduction in developing countries. Matern Child Nutr. 2016;12(S1):106-20. http://doi.org/10.1111/ mcn. 12220 PMid:26542185

24. Rah JH, Cronin AA, Badgaiyan B, Aguayo VM, Coates S, Ahmed S. Household sanitation and personal hygiene practices are associated with child stunting in rural India: A cross-sectional analysis of surveys. BMJ Open. 2015;5(2):e005180. http://doi. org/10.1136/bmjopen-2014-005180 PMid:25678539

25. Puspasari N, Andriani M. Hubungan pengetahuan ibu tentang gizi dan asupan makan balita dengan status gizi balita (BB/U) Usia 12-24 Bulan. Am Nutr. 2017;1(4):369-78.

26. Christiaensen L, Alderman $\mathrm{H}$. Child malnutrition in Ethiopia: Can maternal knowledge augment the role of income? Econ Dev Cult Change. 2004;52(2):287-312.

27. Uliyanti U, Tamtomo DG, Anantanyu S. Faktor yang berhubungan dengan kejadian stunting pada balita usia 24-59 Bulan. J Vokasi Kesehatan. 2017;3(2):67-77.

28. KEMENKES RI. Sanitasi Total Berbasis Masyarakat. Jakarta: Kementerian Kesehatan RI; 2014

29. Al-Kahfi. Gambaran Pola Asuh Pada Baduta Stunting Di Wilayah Kerja Puskesmas Neglasari Kota Tangerang. Jakarta: Universitas Islam Negeri Jakarta; 2015.

30. KEMENKES RI. Peraturan Menteri Kesehatan Republik Indonesia Nomor 492/Menkes/Per/IV/2010. Kementerian Kesehatan RI; 2010.

31. Gibney MJ. Gizi Kesehatan Masyarakat. Jakarta: EGC; 2009.

32. Hapsari DI, Dewi RR, Selviana S. Deteminan kejadian stunting pada balita di wilayah 3t (tertinggal, terdepan, dan terluar) (studi kasus di wilayah kerja puskesmas darajuanti kabupaten sintang). J Publikasi Kesehatan Masyarakat Indones. 2019;6(2):72-8.

Author Queries???

AQ1: Kindly provide ORCID id for all authors. 